\title{
Entrepreneurial innovation, judgment, and decision-making as a virtuous process
}

\author{
Tomás González-Cruz ${ }^{1} \cdot$ Carlos Devece $^{2}$
}

Published online: 29 March 2018

(C) Springer Science+Business Media, LLC, part of Springer Nature 2018

\begin{abstract}
Entrepreneurial Innovation is one of the issues that nowadays arouses the interest of academics and practitioners. Efforts made until now, focus on procedures and context through and where entrepreneurial action is enacted. Recently this interest has turned toward the entrepreneurial mindset (European Commission 2016) that provides intention to the set of competences that the entrepreneur deploys along the innovation process. Through this special issue IEMJ calls for research that provides a better understanding of the entrepreneur's process in looking for and discovering new opportunities for value creation. In this introductory paper a virtuous process is proposed that relies on Austrian School tradition: Entrepreneurial judgement, context understanding, resources and wills mobilization, exploratory leaning and focus on value creation that fit non-served needs.
\end{abstract}

Keywords Entrepreneurial innovation · Entrepreneurial judgement · Value creation

\section{Introduction}

Choosing the title of a special issue is a difficult task. It should be specific enough to justify the special issue's sharp focus on a salient issue that requires particular attention, but it should also appeal to academics who seek a better understanding of the social phenomena that are under study. In this case, and in my opinion, the IEMJ editorial managers have struck this balance. The title of this special issue epitomizes the core elements of entrepreneurial mindset, which is one of the current issues that modern economies, especially in Europe, have yet to address effectively.

Tomás González-Cruz

tomas.gonzalez@uv.es

1 University of Valencia, Valencia, Spain

2 Polytechnic University of Valencia, Valencia, Spain 
Considering innovation and entrepreneurship inevitably leads us to adopt an outsidein focus (McGrath 2010) that relies on the Austrian Economics perspective of these phenomena. From this perspective, entrepreneurship is defined as "the pursuit of opportunity beyond the resources you currently control" (Stevenson 2000: 1). This conceptualization of entrepreneurship brings to the fore the challenge of gaining a better understanding of the core elements that constitute the entrepreneurial mindset (European Commission 2016).

The entrepreneurial mindset is the cornerstone of the value creation process, regardless of whether this value creation occurs in the economic, social, or environmental domain. Therefore, a detailed operational description of the core elements that constitute this mindset is critical for improving the quality of our entrepreneurs and their potential to create value. It is worth considering Bacigalupo et al.'s (2016) theoretical framework, which identifies three main competency areas that constitute the entrepreneurial mindset. These areas coincide with the four elements that are considered in this IEMJ special issue.

The first element is judgment. Kirzner (1997) refers to "pure entrepreneurial judgment" for the early discovery of opportunities in markets where consumer needs are constantly changing. These needs may be explicit or latent, and consumers are sometimes unaware of their real needs. The entrepreneur is the figure who must imagine and design a value proposition to meet these needs. This "entrepreneurial alertness" (Kirzner 1997) to spot new opportunities has been defined as "the general process whereby overt or latent consumer or market demands indicate to entrepreneurs prospects for opportunity creation or discovery" (Priem and Swink 2012: 354). As Penrose (1959) affirms, entrepreneurial discovery is a product of the imagination that requires creativity and knowledge.

Judgment and the imaginative exercise that leads to value creation do not occur in isolation. They require specific knowledge and unique experience. As Hmieleski and Baron (2009) affirm, entrepreneurial activity is based on the entrepreneur's experience with a group of consumers in a given context. This specific knowledge, whose value depends on the circumstances of time and place (Hayek 1945), allows the entrepreneur to recognize consumer needs in ways that other more powerful market constituents cannot (Hill and Birkinshaw 2010). This kind of knowledge, which is a necessary for opportunity signaling, results from close relationships between entrepreneurs and potential consumers (Kor et al. 2007).

The third competence area that constitutes the entrepreneurial mindset is decisionmaking. This meta-competence relates to coping with uncertainty, ambiguity, and risk and having enough resilience to learn from experimentation through trial and error. Entrepreneurs must also have the determination to convince and mobilize others' resources and - the greatest challenge of all — others' will (Bacigalupo et al. 2016).

Lastly, this IEMJ special issue title covers the desired result of entrepreneurial activity: entrepreneurial innovation, or new value creation. Innovation, from an outside-in view, seeks to satisfy current consumer needs in an entirely new way and, if possible, identify new needs for underserved customers (Priem and Swink 2012). This way of understanding innovations highlights the difference between value creation and value capture (Gans and Stern 2010) and stresses the idea that the only opportunity for entrepreneurs to compete with established constituents is to first create value for customers and quickly enter the new market to capture and protect the new created value (Aspara and Tikkanen 2013). 
To close the virtuous circle, this kind of innovation creates knowledge that enables the discovery of new complementary needs that lead to innovations. In fact, Visnjic et al. (2016) show how product innovation fuels the process of service innovations, which in turn create new knowledge for future product innovations.

\section{Contributions}

In "Necessity and opportunity entrepreneurs: Survival factors," Rico and Cabrer-Borras analyze the determinants of survival in entrepreneurship in Spain using information from the Continuous Working Life Sample. The results show that age and nationality are important factors for survival. Education is relevant for necessity entrepreneurs and leads to key differences that influence the survival of necessity and opportunity entrepreneurs.

Budyldina analyzes the effect of university entrepreneurial activities on the regional economy in Russia in "Entrepreneurial universities and regional contribution." The study examines research and patent metrics and entrepreneurial activities. It provides useful insight into the heterogeneous nature of entrepreneurship in Russian universities and maps various dimensions of entrepreneurial activities that are undertaken by regional universities.

Zabelina, Chestyunina, and Tsiring examine "Personal helplessness and self-reliance as predictors of small business development in Russia: Pilot research results." The authors analyze perceptions of young entrepreneurs and civil servants in Russia and find that entrepreneurs are closer to the pole of self-reliance, while public employees are positioned near the pole of personal helplessness.

"Sustainable entrepreneurial orientation within an intrapreneurial context: Effects on business performance," by Criado-Gomis, Cervera-Taulet, and Iniesta-Bonillo, presents an integrated approach to intrapreneurship using survey data for 210 firms in Valencia (Spain). The results provide new insights for the study of sustainable entrepreneurship as a strategic asset within the framework of the dynamic capabilities perspective and present the role of SEO and entrepreneurial activities in business growth.

The next contribution is Kyvik's article on "The global mindset: A must for international entrepreneurship and innovation." Through a systematic review of the literature on the global mindset, the author confirms the relevance of this topic for training future CEOs and stresses the importance of its inclusion in university programs worldwide.

Finally, in "From entrepreneurship potential in culture and creative industries to economic development: The situation of UK and southern European countries," Porfirio, Carrilho, and Felício propose a model to evaluate the way entrepreneurship potential (defined by environmental and psychological factors) influences entrepreneurial self-efficacy results in culture and creative industries using a qualitative comparative methodology.

\section{References}

Aspara, J., \& Tikkanen, H. (2013). Creating novel consumer value vs. capturing value: strategic emphases and financial performance implications. Journal of Business Research, 66(5), 593-602. 
Bacigalupo, M., Kampylis, P., Punie, Y., \& Van den Brande, G. (2016). EntreComp: The entrepreneurship competence framework. Luxembourg: Publication Office of the European Union.

European Commission (2016). Communication from the commission to the council, The European parlamient. Brussels: The economic and social committee and the committee of the regions (381/2).

Gans, J. S., \& Stern, S. (2010). Is there a market for ideas? Industrial and Corporate Change, 19(3), 805-837.

Hayek, F. A. (1945). The use of knowledge in society. The American Economic Review, 35(4), 1-18.

Hill, S. A., \& Birkinshaw, J. M. (2010). Idea sets: conceptualizing and measuring a new unit of analysis in entrepreneurship research. Organizational Research Methods, 13(1), 85-113.

Hmieleski, K. M., \& Baron, R. A. (2009). Entrepreneurs' optimism and new venture performance: a social cognitive perspective. Academy of Management Journal, 52(3), 473-488.

Kirzner, I. M. (1997). Entrepreneurial discovery and the competitive market process: an Austrian approach. Journal of Economic Literature, 35(1), 60-85.

Kor, Y. Y., Mahoney, J. T., \& Michael, S. C. (2007). Resources, capabilities and entrepreneurial perceptions. Journal of Management Studies, 44(7), 1187-1212.

McGrath, R. G. (2010). Business models: a discovery driven approach. Long Range Planning, 43(2), 247261.

Penrose, E. T. (1959). The theory of the growth of the firm. New York: Sharpe.

Priem, R. L., \& Swink, M. (2012). A demand-side perspective on supply chain management. Journal of Supply Chain Management, 48(2), 7-13.

Stevenson, H. H. (2000). Why entrepreneurship has won! Coleman white paper, Graduate school of business administration, Harvard University.

Visnjic, I., Wiengarten, F., \& Neely, A. (2016). Only the brave: product innovation, service business model innovation, and their impact on performance. Journal of Product Innovation Management, 33(1), 36-52. 